Relations industrielles

Industrial Relations

\title{
Ethical Socialism and the Trade Unions: Allan Flanders and British Industrial Relations Reform, By John Kelly, London: Routledge, 2010, 246 pp., ISBN 978-0-415-87848-7
}

\section{Richard Hyman}

Volume 66, numéro 1, hiver 2011

URI : https://id.erudit.org/iderudit/1005110ar

DOI : https://doi.org/10.7202/1005110ar

Aller au sommaire du numéro

Éditeur(s)

Département des relations industrielles de l’Université Laval

ISSN

0034-379X (imprimé)

1703-8138 (numérique)

Découvrir la revue

Citer ce compte rendu

Hyman, R. (2011). Compte rendu de [Ethical Socialism and the Trade Unions: Allan Flanders and British Industrial Relations Reform, By John Kelly, London: Routledge, 2010, 246 pp., ISBN 978-0-415-87848-7]. Relations industrielles / Industrial Relations, 66(1), 150-151. https://doi.org/10.7202/1005110ar

Tous droits réservés @ Département des relations industrielles de l’Université Laval, 2011
Ce document est protégé par la loi sur le droit d'auteur. L'utilisation des services d'Érudit (y compris la reproduction) est assujettie à sa politique d'utilisation que vous pouvez consulter en ligne.

https://apropos.erudit.org/fr/usagers/politique-dutilisation/ 


\section{Recensions / Book Reviews}

\section{Ethical Socialism and the Trade Unions: Allan Flanders and British Industrial Relations Reform}

By John Kelly, London: Routledge, 2010, 246 pp., ISBN 978-0-415-87848-7

Allan Flanders was born in 1910 and died in 1973, after having contracted a disabling illness. As a colleague of Hugh Clegg, with whom he edited The System of Industrial Relations in Great Britain in 1954, he was one of the founders of the 'Oxford School' of industrial relations (a label which its members usually rejected). Of this group of scholars, who dominated the 'pluralist' analysis of the 1950s and 1960s, Flanders stood out through his concern with questions of theory and his interest in American writing on the subject. (In a review of Industrial Relations Systems he wrote: 'My sympathies are wholly with John Dunlop in choosing to spend his year on leave in Geneva to work on the theory of industrial relations.... What I doubt, having read the results of his work in this decidedly stimulating book, is whether a year was long enough.') His attempt to write a broad theory of trade unionism was left incomplete. Two of his works were particularly influential: his 1966 book The Fawley Productivity Agreements and his 1967 essay Collective Bargaining: Prescription for Change. The latter, his evidence to the Donovan Commission, was decisive in forming the Commission's conclusion that the institutions of British industrial relations required fundamental reconstruction, but that change could not be imposed through legislative fiat (as many politicians supposed); it required the voluntary assent of the key actors.

Less well known was his curious political trajectory. For most of the last three decades of his life he edited Socialist Commentary, which became one of the most important vehicles of right-wing revi- sionism in the post-war Labour Party. Yet the route to this position was remarkable. In his late teens he encountered the Internationaler Sozialistischer Kampfbund (ISK, International Socialist League of Struggle or Militant Socialist International), a small German revolutionary group which rejected both capitalism and Marxism. The ISK shared with Leninism a belief in the revolutionary role of an elite cadre party, but drew from philosophers such as Kant an insistence on the ethical basis of social transformation and in the power of rational argument. It was also strongly anti-clerical, and committed to teetotalism and vegetarianism. In 1929 Flanders, who did not initially speak German, went to spend three years at the ISK cadre school. On his return he assumed leadership of the tiny British section, which adopted the name Socialist Vanguard.

In this book, Kelly traces the route from left-wing revolutionary (albeit of an unusual kind) to right-wing social democrat. (A similar path was followed by the ISK leader, Willi Eichler, who in 1959 was the main author of the revisionist Bad Godesberg programme of the German social democrats, though Kelly does not discuss this.) The shift commenced shortly before the war, when Flanders became convinced, first that revolutionaries needed a concrete set of policy proposals, and second that there was no realistic alternative to working within the Labour Party. His persistent rejection of orthodox communism was reinforced by the StalinHitler pact of 1939. The ISK, and Flanders, strongly supported the war against Nazi Germany. As the war proceeded, his revolutionary convictions gave way to the view that capitalism could be transformed from within, and that this was indeed occurring through a process of 'planned capitalism'. The logical corollary was that a revolutionary party was now redundant, and indeed the ISK was dissolved at the end of the war, though the Socialist Vanguard group continued until 1950. 
Kelly regards the commitment to ethical socialism as an enduring element in Flanders' views despite the radical alteration of other elements. But the meaning of these ethics was substantially reinterpreted. The idea of 'fellowship' encouraged a vision of the enterprise as a community in which all could and should participate for their mutual benefit. Anti-materialism informed the view that workers' main needs were for voice, dignity and status rather than higher wages, and trade unions should reflect this. The trust in the power of rational discussion persisted. All these assumptions underlay his commitment to incomes policy, productivity bargaining and industrial relations reform. Kelly itemises some of the contradictions in this position: in a society shaped by fundamental class differences of wealth and power, the 'reform' of industrial relations seemed primarily a recipe for re-stabilising capitalism. Workers and their unions refused to buy the package, and by the end of the 1970s - after Flanders' death - the whole reform project had failed. Kelly ends with an epilogue tracing the familiar story of the past three decades: the shift to a coercive anti-union 'solution' to British industrial relations under Thatcher, a policy position not fundamentally altered under subsequent governments; and the further rightwards shift of social democracy towards 'New Labour', a trajectory which, Kelly concludes, involved 'a radical assault on the ethical and democratic socialist project associated with Allan Flanders'.

The book is the product of an intensive process of research, involving a comprehensive reading of Flanders' published and unpublished writings, extensive archival work, and interviews and correspondence with many of his key associates. It has been a long project, with much of the research undertaken more than a decade ago. Kelly certainly disagrees with many of Flanders' ideas and policy interventions, but the account strikes me as fair and not unsympathetic. I have some disagreements.
The failure of the reform project in British industrial relations surely owed something to the specific circumstances of the 1970s: the collapse of the post-war international financial architecture, the oil shock (an outcome was an inflation rate of $24 \%$ in the UK in 1975), the insistence of the Callaghan government at the end of the decade in imposing an incomes policy so restrictive that breakdown was inevitable. None of this could have been predicted while Flanders was still alive. I am also conscious, having for a few years been a student and then a colleague of Flanders and having disagreed profoundly with his politics, that the scenarios developed by those of us on the revolutionary left were as thoroughly discredited as those of the reformists. I also think Kelly is too dismissive of some of the ethics that Flanders espoused. Can we write off the potential of reasoned argument, or is the question rather to diagnose its limits? And is the proposition that trade unions should do more than fight for higher wages necessarily wrong? Marxist theories of alienation - and indeed also of workers' control - have informed strategies which are not wholly at odds with those which Flanders inherited from the ISK.

\section{Richard Hyman}

London School of Economics

\section{Working Life: Renewing Labour Process Analysis}

Edited by Paul Thompson and Chris Smith, Houndmills, Basingstoke, UK: Palgrave Macmillan, 2010, 350 pp., ISBN 978-0-23022223-6

Each year a volume of essays is published in connection with the convening of the International Labour Process Conference. Usually, these collections are devoted to a specific theme such as skill trends in contemporary economies, work-life balance, creative labour or knowledge management. This volume stands out as one of the periodic paradigm 'stock taking' exercises, only the second such initiative since 1990 . Thus 